\title{
Fatal bone marrow embolism in a patient with sickle cell $\beta^{+}$thalassaemia
}

\author{
Y Zaidi, M Sivakumaran, C Graham, R M Hutchinson
}

\begin{abstract}
Sickle cell $\beta^{+}$thalassaemia is regarded as the mildest of the sickle cell haemoglobinopathy syndromes with a benign natural course. In contrast to sickle cell disease, severe life threatening complications are not usually associated with this genotype. A case of a 30 year old West Indian man who, previously asymptomatic for 10 years, sustained a fatal pulmonary bone marrow embolism, is reported. This case report illustrates that serious, even fatal, complications may occur in patients with this 'benign' condition and bone marrow embolism should be included in the differential diagnosis of acute crisis in these patients.

( $¥$ Clin Pathol 1996;49:774-775)
\end{abstract}

Keywords: bone marrow embolism, sickle cell $\beta^{+}$ thalassaemia.

Sickle cell $\beta^{+}$thalassaemia is regarded as the mildest of the sickle cell haemoglobinopathies and usually has a benign natural course. ${ }^{1}$ The haematological and clinical severity is inversely proportional to the quantity of haemoglobin A $(\mathrm{HbA})$ inherited, ${ }^{23}$ with a higher incidence of leg ulceration, acute chest syndromes and priapism occurring in patients with sickle cell $\mathrm{B}^{\circ}$ thalassaemia than in those with sickle cell $\beta^{+}$ thalassaemia. ${ }^{1}$

Fat embolism is a well known complication of bone marrow infarction in patients with homozygous sickle cell disease ${ }^{45}$ and haemoglobin SC disease, ${ }^{46}$ but is very rare in sickle cell $\beta^{+}$thalassaemia syndrome; only one such case has been reported in the literature. ${ }^{7}$ Here, we report a case of bone marrow embolism occurring in a patient with clinically silent sickle cell $\beta^{+}$thalassaemia, with a fatal outcome.

\section{Case report}

The patient, a West Indian man, was diagnosed as having sickle $\beta^{+}$thalassaemia when 17 years of age. The results of the investigations carried out at presentation were as follows: haemoglobin $13.0 \mathrm{~g} / \mathrm{dl}$; mean corpuscular volume 68 $\mathrm{fl}$; mean corpuscular haemoglobin $22.9 \mathrm{pg}$; $\mathrm{HbF} 6.2 \%$; HbA $25 \%$; and HbA2 5.8\%. The peripheral blood film showed target cells and occasional sickle cells. Apart from an episode of acute splenic sequestration at the age of 18 , the patient remained well and asymptomatic until the age of 30 , when he was admitted to hospital with shoulder and abdominal pains of acute onset following an episode of upper respiratory tract infection. Clinical examination revealed pallor and tachycardia but was otherwise unremarkable. Full blood count analysis of revealed a haemoglobin of $7.0 \mathrm{~g} / \mathrm{dl}$, white cell count of $19.4 \times 10^{9} / 1$ and platelet count of 379 $\times 10^{9} / 1$. HbS was $71 \%$ and the serum biochemistry, arterial blood gas analysis and chest $x$ ray were normal. Suspected painful crisis was treated with intravenous fluids, pethidine, antibiotics, and oxygen. His symptoms initially responded to the treatment but 12 hours later the patient developed severe difficulty in breathing. On examination, he was orthopneic and cyanosed. Auscultation of the chest $c$ revealed scattered crepitations and occasional rhonchi. There were no petechiae on the skin or in the conjunctivae and examination of central nervous system was unremarkable. Fundoscopy was normal. Within a few minutes of developing shortness of breath, the patient sustained a cardiorespiratory arrest. An electrocardiograph showed electromechanical dissociation. Radiological examination was not carried out. Attempts at resuscitation failed and the patient died of anoxia.

\section{Necropsy findings}

MACROSCOPIC FINDINGS

Occlusive thrombus in the right pulmonary artery and numerous emboli in the pulmonary arterioles of both lungs. There was no evidence of pulmonary infarction.

\section{MICROSCOPIC FINDINGS}

The emboli consisted of cellular haemopoietic bone marrow and scattered rigid fat spaces. Some of the emboli were associated with fibrin. Capillaries within the alveolar walls were of plugged with sickle shaped erythrocytes but no $N$ thrombi. Surrounding lung parenchyma was oedematous. Similar plugging by sickle shaped red cells was seen in the liver sinusoids, renal and brain capillaries.

The spleen was shrunken, fibrotic and contained several Gamna-Gandy bodies. The bone marrow showed areas of necrosis. Necropsy of the brain was not performed.

\section{Discussion}

Fat embolism in sickle cell syndromes is well described, but rare, ${ }^{8}$ and has been reported in homozygous sickle cell disease ${ }^{45}$ and haemo- $\frac{\sigma}{2}$ globin SC disease. ${ }^{46}$ Occurrence of bone marrow embolism in sickle cell $\beta^{+}$thalassaemia is very rare; only one case has hitherto been reported in the literature. ${ }^{7}$ Our patient was unusual in that he developed such a severe 
complication despite a relatively high $\mathrm{HbA}$ concentration. This observation raises the question whether the patient had another, co-existing red cell defect-for example, another globin chain defect or a membrane defect which influenced the clinical course. Although morphological features of the red cells did not suggest an obvious red cell membrane defect and the haemoglobin electrophoresis did not reveal any other demonstrable abnormality, the above possibilities cannot be ruled out entirely. Furthermore, determination of the molecular defect of the $\beta$ globin chain responsible for the $\beta$ thalassaemia trait in this patient would have given valuable additional information as to whether a particular defect predisposes to more serious complications such as fat/bone marrow embolism.

The pathogenesis of fat embolism in sickle cell syndromes is unclear. It is thought to arise as a result of bone marrow infarction but the reason why some infarctions result in embolisation and most do not is unknown. Vasoocclusion in the marrow capillaries as a result of sickling may play a role. ${ }^{9}$

Antemortem diagnosis of bone marrow embolism is difficult and most of the cases reported in the literature have been diagnosed, as in our case, after death. Refractory bodies (fat globules) may be visible in the optic fundi. ${ }^{6}$ Infarction of bone marrow may be demonstrated by bone scintigraphy ${ }^{8}$ or magnetic resonance imaging. ${ }^{10}$ Demonstration of fat globules in urinary sediment, ${ }^{11}$ sputum macrophages ${ }^{5}$ or bronchial washings ${ }^{12}{ }^{13}$ has been used successfully in establishing an antemortem diagnosis.
In view of the serious nature of this condition, prompt treatment is indicated. Exchange transfusion has been found to be the most effective therapeutic modality. ${ }^{56}$ Heparin and corticosteroids may also be beneficial. ${ }^{6}$

The authors thank Dr G Saldanha for technical assistance.

1 Embury SH. Sickle cell disease. In: Hoffman R, Benz EJ, Shattil SJ, Furie B, Cohen HJ, Silberstein LE, eds. Haematology: basic principles and practice. New York: Churchill Livingstone, 1995:611-40.

2 Christakis J, Vavatsi N, Hassapopoulou H, Angeloudi M Papadopoulou M, Loukopoulos D, et al. A comparison of sickle cell syndromes in Northern Greece. Br $\mathcal{F}$ Haemato 1991;77:386-91.

3 Serjeant GR, Sommereux AM, Stevenson M, Mason K, Serjeant BE. Comparison of sickle cell $B$ thalassaemia and homozygous sickle cell disease. Br f Haematol 1979;41:8393.

4 Shelly WM, Curtis EM. Bone marrow and fat embolism in sickle cell anaemia and sickle cell $\mathrm{HbC}$ disease. Bull fohn Hopkins Hosp 1958;103:8-25.

5 Hutchinson RM, Merrick MV, White JM. Fat embolism in sickle cell disease. $\mathcal{F}$ Clin Pathol 1973;26:620-2.

$6 \mathrm{Chmel} \mathrm{H}$, Bertles JF. HbSC disease in a pregnant female with crisis and fat embolism syndrome $A m \mathcal{F} M e d$ $1975 ; 58: 563-6$.

7 Johnson K, Stastny JF, Rucknagel BL. Fat embolism syndrome associated with asthma and sickle cell B + thalassaemia. Am f Hematol 1994;46:354-7.

8 Charache S, Page DL. Infarction of bone marrow in sickle cell disorders. Ann Intern Med 1967;67:1 195-200.

9 Shapiro MP, Hayes JA. Fat embolism in sickle cell disease. Arch Intern Med 1984;144:181-2.

10 Mankad VN, Williams JP, Harpen MD, Manci E, Longereker G, Brogden BG. Magnetic resonance imaging of bone marrow in sickle cell disease: clinical, haematologic and pathologic correlation. Blood 1990;75:274-83.

11 Herndon JH. The syndrome of fat embolism. South $7 \mathrm{Med}$ 1975;68: $1577-84$

12 Chastre J, Fagan JY, Soler P, Fichellei A, Dombret MC, Huten $\mathrm{D}$, et al. Bronchoalveolar ravage for rapid diagnosis of the fat embolism syndrome in trauma patients. Ann of the fat embolism syndrom

13 Bannier B, Poirier T, Viaud JY, Laurens E, Tubide A. Fat embolism diagnostic interest of the bronchoalveolar lavage [letter]. Intensive Care Med 1992;18:59-60. 